\title{
The Effect of Social Media on Reading Intensity of Fifth Grade Elementary School Students
}

\author{
Pratiwi Kartika Sari \\ Faculty of Teacher Training and Education \\ Universitas Muhammadiyah Jakarta \\ Tangerang Selatan, Indonesia \\ *tiwikartika@umj.ac.id \\ Otto Fajarianto* \\ Faculty of Social and Political Studies \\ Universitas Swadaya Gunung Djati \\ Cirebon, Indonesia \\ ofajarianto@gmail.com
}

\author{
Deti Rostini \\ Faculty of Teacher Training and Education \\ Universitas Islam Nusantara \\ Bandung, Indonesia \\ yankty59@gmail.com \\ Yuyun Safitri \\ Faculty of Teacher Training and Education \\ IKIP PGRI \\ Pontianak, Indonesia \\ yuyun.ikip.pgri@gmail.com
}

\begin{abstract}
The purpose of this study was to examine the effect of social media use on the intensity of reading fifth grade elementary school students. This research was conducted in Public Elementary Schools in Ciledug Sub district. The method used in this study is a quantitative method. The results showed that 1) the reading intensity of grade $V$ elementary school students is still high, this can be seen from the results of the questionnaire analysis which shows that fifth grade elementary school students are still routinely reading even though he uses social media. 2) There is an influence on the use of social media on the intensity of reading Elementary School class $\mathrm{V}$ students. This can be seen based on a simple correlation analysis. The $r$ value states that the number of numbers between $0,00-0,199$ has a "very low" level of influence because the product correlation the moment above amounted to 0.089 . Based on the coefficient of determination variable $X$ (use of social media) contributes to the variable $Y$ (reading intensity of grade $V$ elementary school students) of $0.8 \%$ while the remaining $99.2 \%$ is influenced by other variables outside the research.
\end{abstract}

Keywords: intensity, reading, social media

\section{INTRODUCTION}

Education is a mode to enrich the life of a nation. By education, it is expected to produce qualified and responsible humans who are able to welcome future progress. Based on the form, education can be divided into two, there are: Formal education and non-formal education.

Learning activities are the most basic activities in the process of education. It means that the success or failure of achieving educational goals depends a lot on how the learning process experienced by students as learners. According to Slameto [1] the factors that influence student learning outcomes are classified into two, namely: internal factors and external factors. Internal factors are factors that exist inside the individuals who are learning, while external factors are factors that exist outside the individual.
The term of social media has grown very popular among internet users especially in the sense of being universal and widely used [2]. The development of information technology today is growing rapidly. Today there are many things have produced from the development of information technology, such as the development of gadgets and social media. We can see that social media has become increasingly attached to people's lives so that children from elementary school also feel the development of this technology. It is not a secret anymore that the popularity of various forms of social media has grown rapidly for leisure and works related tasks [3]. But what are worried in responding to the development of this technology is students who are too absorbed in playing their gadgets to access various kinds of social media inside them to student reading activities. The elementary school students' upper grade who have reading problems may have difficulty in one or more reading scopes, each requiring a special type of intervention [4], so that it can lead to reduce the interest in reading for elementary school students. What is supposed to be in elementary school is the beginning of developing the interest in reading, but with the rise of technological developments whether the intensity of student reading is become reduced or even increased. As the closest environment, the family through parenting greatly influences the level of children's development and plays a role in monitoring children's behaviour including the behaviour of using social media [5].

As in the research study from Dyah Sari Rasyidah 2017 it was stated that, Grade VIII students in SMPN 3 Karangdowo Klaten use social media in the form of Facebook as many as 30 students with a percentage of $33 \%$ while students who use $\mathrm{BBM}$ as many as 26 students with a percentage of $28 \%$, students who use both (Facebook and BBM) as many as 23 students with a percentage of $25 \%$, and there are 12 children not using social media at all with a percentage of $14 \%$. In testing the hypothesis of the use of social media with student learning intensity obtained a count of $0.411>0.05$ then Ho is 
accepted, means that there is no influence between the uses of social media with the intensity of PAI learning [6].

In the Big Indonesian Dictionary, the usage can be interpreted as a process, method, act of using something [7]. The Graphic, Visualization \& Usability Centre, The Georgia Institute of Technology [8] classifies the use of the internet into three categories based on the intensity of interest used, namely: 1) Heavy Users (more than 40 hours per month, 2) Medium Users (between 10 to 40 hours per month), 3) Light Users (less than 10 hours per month).

Kaplan and Haenlein in the Journal of the Influence of Social Media on Social Change Society in Indonesia defines "Social media is a group of networks based on application in the internet that are built on web 2.0 technology, so that it can make users create and replace content that is distributed. Social media and social software are tools to improve the ability of users to share, to co-operate between users and take collective action which are all outside the institutional or organizational framework [9]. Social media as any online platform that allows users to link to each other, to contribute, and to share content or comments [10]. Social media is social interaction between humans in producing, sharing and exchanging information, it includes ideas and sharing content in virtual communities [11].

It can be concluded that social media is an online media with its users can easily participate, communicate, share, and create content including communication, content, and context as well as how many social media accounts it has. So the use of social media is the process of using an online media usage with its users can easily participate, communicate, share, and create content including communication, content, and context as well as how many social media accounts it has. Intensity is a state of level or intensity measure.

Reading is a process carried out and used by readers to get messages, which the writer wants to convey through the media of words / written language [12]. Reading is a very important and useful activity for someone's life because it makes a person have extensive knowledge and insight [13]. Reading is the rate of decomposition of writing, a reading analysis [12]. Thus reading is the capture and understanding of ideas, the reader activity which is accompanied by an outpouring of the soul in appreciating the script.

Based on the results from several opinions regarding reading, it can be concluded that reading is a process carried out by readers to obtain a message that includes skills, understanding, and efficiency. After many explanations on the definition of intensity and understanding of reading, so the writer concludes that the intensity of reading is a reading activity carried out by a person in a routine period of time each day to achieve the desired results.

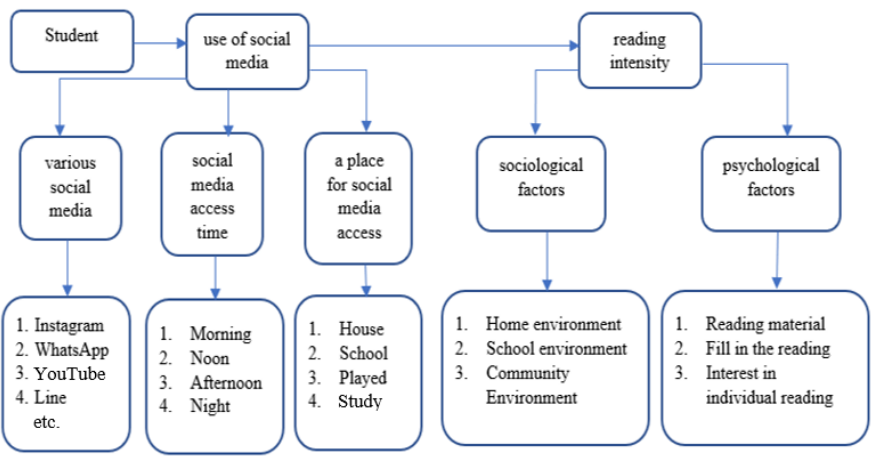

Fig. 1. Framework of thinking.

Based on the study of theory and framework of thinking, then the researchers propose this research hypothesis that is in order to answer the first problem of how the use of social media does it affect to the reading intensity of fifth grade elementary school students.

\section{Methods}

This research is carried out in the State Elementary School located in Peninggilan Village, Ciledug Sub-District, Tangerang City, Banten District, which has 7 State Elementary Schools, there are: State Elementary Schools Peninggilan 01, State Elementary Schools Peninggilan 02, State Elementary Schools Peninggilan 03, State Elementary Schools Peninggilan 04, State Elementary Schools Peninggilan 05, State Elementary Schools Peninggilan 06, State Elementary Schools Peninggilan 07. This research was done in December 2018 until January 2019.

The research method used in this research is a quantitative approach with a non-experimental research design, namely correlational research (relationships / associations). The population in this research was all students fifth grade at the State Elementary School in Paninggilan Village, Ciledug subdistrict, Tangerang District, totalling 662 students from seven state schools in Paningilan Village.

The sample in this research were 234 students which spread in each school with the calculation: The State Elementary School Peninggilan 01 with 28 students from fifth grade, The State Elementary School Peninggilan 02 with 36 students from fifth grade, The State Elementary School Peninggilan 03 with 36 students from fifth grade, The State Elementary School Peninggilan 04 with 28 students from fifth grade, The State Elementary School Peninggilan 05 with 34 students from fifth grade, The State Elementary School Peninggilan 06 with 34 students from fifth grade, The State Elementary School Peninggilan 07 with 38 students from fifth grade.

This research used several data collection techniques, namely questionnaire and study documentation. Basically, this data collection technique is carried out to find out the results of the research so the data collection is done. Basically, this data collection technique is carried out to find out the results of the research so the data collection is done [14]. 


\section{RESULTS AND DiSCUSSION}

The important contribution of the two fields can be seen in a discussion of the underlying teaching techniques related to the use of AR; and taxonomy which classifies the various aspects of mobile AR to study in a variety of situations. AR as an alternative medium of learning in the future. In the past, the limitations of AR technology are only used in one place cannot be moved around. However, the development of AR continues to do so has been obtained AR a portable or can be taken anywhere. Utilization of AR in the world of education to the introduction of animals to early childhood through smartphone devices and cards [15].

Implementation of flash card method packaged in various forms of play activities and early reading learning is expected to improve the early reading ability of children. To answer the problem and achieve the expected capability then with flash card method, the early reading learning activities become easier for the child and can improve the vocabulary quickly. In this case the researcher uses classroom action research methods in the learning process. The subject of this research is the group of B TK Kasih Ibu Tangerang. Learning design is to apply the method of flash card in an effort to improve the ability to read early. The results of this study indicate that the method of flash card can improve children's early reading ability. This can be seen from the children's early reading ability that continues to increase in each cycle [16].

Based on previous research it can be seen that the use of technology and other devices can improve students' reading abilities. At this time not only technology can affect students 'interest in reading, but we can also use social media as a tool to develop students' reading skills.

The results of this research were obtained based on the results of measurements using a questionnaire. Based on data obtained from the results at the time of the research with the number of items consisting of 20 items of variable $\mathrm{X}$ questions (use of social media) and 20 items of variable Y questions (reading intensity).

The use of social media variable $(\mathrm{X})$ obtained data through questionnaire that given to 234 students of fifth grade, this questionnaire consisted of 20 statements. Based on the calculation of the data description, the influence of the use of social media obtained 234 data, with a total of 17.754, an average value (mean) 75.87, a median value (median) 75.97, most values (mode) 81, standard deviation 7.200, variance 51.846, minimum 49, and a maximum of 96

Meanwhile the reading intensity variable (Y) obtained data through questionnaire that given to 234 students of fifth grade, this questionnaire consisted of 20 statements. Based on the calculation of the reading intensity data description obtained data from 234 students of class $v$ with a number of 19,423, the average value (mean) 83.00, the middle value (median) 83,30, the most value (mode) 81 , standard deviation 7,287, variance 53,103, minimum 61, maximum 98 .
TABLE I. VARIABLE RELIABILITY TEST X

\begin{tabular}{|c|c|}
\hline Cronbach's Alpha & N of items \\
\hline 850 & 20 \\
\hline
\end{tabular}

Based on the table above shows that the results of the reliability test analysis note that the questionnaire of variable $\mathrm{X}$ (Use of Social Media) obtained a reliability value (Cronbach's Alpha) of 0.850 declared reliable stronger because the reliability value (Cronbach's Alpha) is greater than 0.5 .

TABLE II. VARIABLE RELIABILITY TEST Y

\begin{tabular}{|c|c|}
\hline Cronbach's Alpha & N of items \\
\hline 802 & 20 \\
\hline
\end{tabular}

Based on the table above shows that the results of the reliability test analysis note that the questionnaire of variable $\mathrm{Y}$ (Intensity of Reading) obtained a reliability value (Cronbach's Alpha) of 0.802 which was stated to be reliable because the reliability value (Cronbach's Alpha) was greater than 0.5 .

Kolmogorov Smirnov $\mathrm{Z}$ on the $\mathrm{X}$ variable is 936, and the Asymp value. Sig $X$ is 312 . Based on the decision result that the Asymp value. Sig divided 2, $0.05 / 2=0.025$ from these results it can be concluded that we can say that $0.936>0.025$ distribution of residual data is normal.

Kolmogorov Smirnov $\mathrm{Z}$ on the $\mathrm{Y}$ variable is 827 , and the Asymp value. Sig Y is 502. It can be concluded that these two methods show good results and the calculated data can be said that the residual data distribution is normal. So thus, the data on the two variables are declared normal because more than X2 arithmetic or 0.05 on those data.

The relationship between the use of social media on the reading intensity of fifth grade elementary school students produced a $F$ value $=0.994$ with a significance value $=0482$. It is said that there is a linear relationship, if the significance value $>0.05$, here the significance $=0.482$ which is greater than 0.05 . Then it can be concluded that the relationship between the two variables is linear.

The relationship between the use of social media with the reading intensity of fifth grade elementary school students has a significant similarity because the regression coefficient is 0.090 and the calculation result $\mathrm{F}$ count $=76.164$ with a probability significance level $0.000<0.05$, then the regression model can be used to predict the $\mathrm{Y}$ variable.

At the constant 76,164, while the value of $t$ count $=1.362$ with a significance value of $0.174>0.05$, then Ho is rejected and $\mathrm{Ha}$ is accepted, which means there is no significant influence of the independent variable $(\mathrm{X})$ and the dependent variable $(\mathrm{Y})$

By getting the magnitude of rxy 0.089 illustrates that the correlation is significant at the significance level of 0.01 . The value of 0.174 illustrates the extent of the significance level of 1 - the end of the correlation coefficient above 0.05 at the positive direction, so the correlation of variable $\mathrm{X}$ with variable $\mathrm{Y}$ can be concluded significant. With a value of 0.089 , there is 
an influence between the influences of the use of social media on the reading intensity of fifth grade elementary school students. The correlation coefficient value $r$ of the amount of numbers between $0.00-0.199$ has "very low" level of relationship because the results of the product moment correlation above amounted to 0.089 .

\section{CONCLUSION}

The influence of the variable use of social media $(\mathrm{X})$ on the reading intensity of fifth grade elementary school students $(\mathrm{Y})$ was $0.8 \%$. While the remaining $99.2 \%$ is influenced by other factors, from what researchers did during the research by finding out about the daily activities of students who became research samples, by re-analysing in several schools using a questionnaire consisting of several questions and have answers that appropriate to their answers. After repeated research it turns out that the time students use to play social media is not too often, but only occasionally in a day, and even then to reply to text messages from WhatsApp, then continued with learning and reading books it was proven by the results of a questionnaire stating that elementary school students do not always use gadgets to play social media all the time, because the questionnaire statement at point number 1 that reads "I access social media anytime" is calculated by the number of scores only 872 from the expectation total score of 1,170 , means that many other variables affect the intensity of reading, not only with the use of social media.

\section{REFERENCES}

[1] Slameto, Belajar dan faktor-faktor yang mempengaruhinya, Jakarta: PT Rineka Cipta, 2010.

[2] I. Destiana and A. Salman, "The acceptance, usage and impact of social media among university students," e-Bangi, vol. 12, no. 4, 2015.
[3] C. Tenopir, R. Volentine, and D.W. King, Social media and scholarly reading, Online Information Review, 2013.

[4] K.D. Ritchey, K. Palombo, R.D. Silverman, and D.L. Speece, "Effects of an informational text reading comprehension intervention for fifthgrade students," Learning Disability Quarterly, vol. 40, no. 2, pp. 68-80, 2017.

[5] K. Prabandari and L.N. Yuliati, "The influence of social media use and parenting style on teenagers' academic motivation and academic achievement," Journal of Child Development Studies, vol. 1, no. 1, pp. 39-53, 2016.

[6] S.R. Dyah, Pengaruh Penggunaan Media Sosial dan Jenis-jenis Media Sosial Terhadap Intensitas Belajar PAI Siswa Kelas VIII Di SMP N 3 Karangdowo Klaten (Thesis), Surakatra: IAIN, 2017.

[7] Departemen Pendidikan Nasional, Kamus Besar Bahasa Indonesia, Jakarta: Balai Pustaka, 2002.

[8] A.N. Qomariyah, "Perilaku penggunaan internet pada kalangan Remaja Perkotaan. Palimpsest Jurnal Ilmu Informasi dan Perpustakaan,” vol. 1, no. 1, pp. 110-115, 2009.

[9] R. Nasrullah, Media Sosial: Perspektif Komunikasi, Budaya, dan Sosioteknologi, Bandung: Simbiosa Rekatama Media, 2016.

[10] Y.B. Rachman, "Social Media Application in Indonesian Academic Libraries," Webology, vol. 15, no. 1, 2018

[11] S. Feri, Web Marketing, Jakarta: PT Elex Media Komputindo, 2009.

[12] S. Kundharu and Y. Slamet, Pembelajaran Keterampilan Berbahasa Indonesia: Teori dan Aplikasi, Yogyakarta: Graha Ilmu, 2014.

[13] L. Priahandini, "Pengaruh intensitas membaca terhadap hasil belajar IPS siswa kelas V SD se-Gugus II Kecamatan Pengasih Kabupaten Kulon Progo tahun pelajaran 2014/2015," Basic Education, vol. 5, no. 2, pp. 121-128, 2016.

[14] Sugiyono, Metode Penelitian Pendidikan:Pendekatan Kuantitatif, Kualitatif, dan R\&D, Bandung: Alfabeta, 2015.

[15] O. Fajarianto, M.I. Setiawan, A. Mursidi, D. Sundiman, and D.A.P. Sari, "The Development of Learning Materials for Introduction of Animals in Early Childhood Using Augmented Reality," International Conference on Knowledge Management in Organizations, pp. 722 727, 2018.

[16] E. Fitria, R. Nasution, O. Fajarianto, and N. Ainal Wardah, "Increasing Ability Reading by Flash Card Method in Children Age 5-6 Years in Kindergarten Kasih Ibu Kec. Periuk Kota Tangerang," Atlantis Press, 2019. 